\title{
A priming effect of LH-RH on the pituitary in rams
}

\author{
T. Stelmasiak and D. B. Galloway \\ Department of Veterinary Clinical Sciences, University of Melbourne, Princes Highway, \\ Werribee, Victoria 3030, Australia
}

In the female rat a single injection of LH-RH causes a rapid release of LH and primes the pituitary so that a further injection $1 \mathrm{~h}$ later produces a significantly increased response (Aiyer, Chiappa \& Fink, 1974). A similar, although not so well pronounced, phenomenon occurs in ewes (Crighton \& Foster, 1977) and women (Rommler \& Hammerstein, 1974; Olivier \& Faure, 1976; Wang, Lasley, Lein \& Yen, 1976). Such a priming effect of LH-RH on LH has not been reported in male domestic animals; we therefore investigated the possibility in rams.

Seven mature, sexually active Merino and 2 Border-Leicester rams were used. The animals were kept in controlled conditions indoors and the experiment was conducted in November (spring). Blood samples were collected into heparinized tubes at 10 -min intervals and injections were made through indwelling catheters placed in the jugular vein. Plasma samples were stored at $-20^{\circ} \mathrm{C}$ until assayed for LH.

Three blood samples were collected before giving the first intravenous injection of $1 \mu \mathrm{g} \mathrm{LH}-\mathrm{RH}$ (Lutal, Hoechst A. G.) dissolved in $1 \mathrm{ml} \mathrm{0.154} \mathrm{M-NaCl}$ (saline). Sampling continued for $1 \mathrm{~h}$ and a second injection of $1 \mu \mathrm{g} \mathrm{LH}-\mathrm{RH}$ was given. Samples were then collected for a further $2 \mathrm{~h}$.

The response of 5 experimental Merino rams treated with two injections of LH-RH was compared with the response of 4 control rams treated with saline as follows. In one of two Merino (M) rams saline was used instead of the first LH-RH injection. In the other, examined simultaneously, saline replaced the second LH-RH injection. Two Border-Leicester (BL) rams were also used as controls with saline replacing the first LH-RH injection on one occasion and the second LH-RH injection on another. No breed differences were noted in response to these injections and the results are combined in Table 1 to give 3 control rams $(2 \mathrm{BL}, 1 \mathrm{M})$ for each treatment.

Plasma LH concentration was measured by a double-antibody radioimmunoassay method similar to that of Hopkinson, Pant \& Fitzpatrick (1974) except that goat anti-equine gamma-globulin serum was used instead of the rabbit preparation and NIH-LH-S18 was used as a standard. All samples were measured in a single assay in which the within-assay variation was $4 \%$. The plasma $\mathrm{LH}$ concentration and the precision of the assay were calculated by the computer programme described Burger, Lee \& Rennie (1972). The variations in plasma LH concentration over time (Text-fig. 1) were calculated for each ram, the area under the curve (ng LH/ml/60 min) being estimated by the trapezoidal rule (Normand \& Fortier, 1970). The area under the first curve (Text-fig. 1) represented the total increment in $\mathrm{LH}$ after the first injection because basal pretreatment levels in all experimental rams were below the sensitivity of the assay $(0.30 \mathrm{ng} / \mathrm{ml})$. The increments in LH during the $60 \mathrm{~min}$ after the second injection were calculated from the areas under the second curve (Text-fig. 1) by subtraction of the estimated residual response from the first injection. The residual areas were found by extrapolation of the first curve to the base line. The mean $\mathrm{LH}$ response to $1 \mu \mathrm{g} \mathrm{LH}-\mathrm{RH}$ or saline during the $60 \mathrm{~min}$ after each injection were compared (Table 1) by using the paired $t$ test.

Table 1. Effect of two injections of $1 \mu \mathrm{g} \mathrm{LH}-\mathrm{RH} 1 \mathrm{~h}$ apart on plasma LH levels in intact rams

\begin{tabular}{cccccc}
\hline & \multicolumn{2}{c}{ Treatment } & \multicolumn{2}{c}{ Mean $( \pm$ S.E.M.) response* } & Significance \\
\cline { 5 - 6 } $\begin{array}{l}\text { No. of } \\
\text { rams }\end{array}$ & 1st injection & 2nd injection & $\begin{array}{c}\text { 1st injection } \\
(0-60 \mathrm{~min})\end{array}$ & $\begin{array}{c}\text { 2nd injection } \\
(60-120 \mathrm{~min})\end{array}$ & $\begin{array}{c}\text { of } \\
\text { difference }\end{array}$ \\
\cline { 2 - 5 } & LH-RH & LH-RH & $4.23 \pm 1.01$ & $10.49 \pm 1.01$ & $P<0.01$ \\
5 & Saline & LH-RH & $0.54 \pm 0.16$ & $4.44 \pm 0.58$ & $P<0.001$ \\
3 & LH-RH & Saline & $3.45 \pm 0.74$ & $0.78 \pm 0.12$ & $P<0.001$ \\
\hline
\end{tabular}

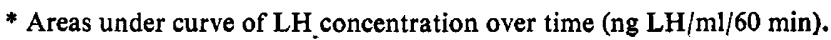




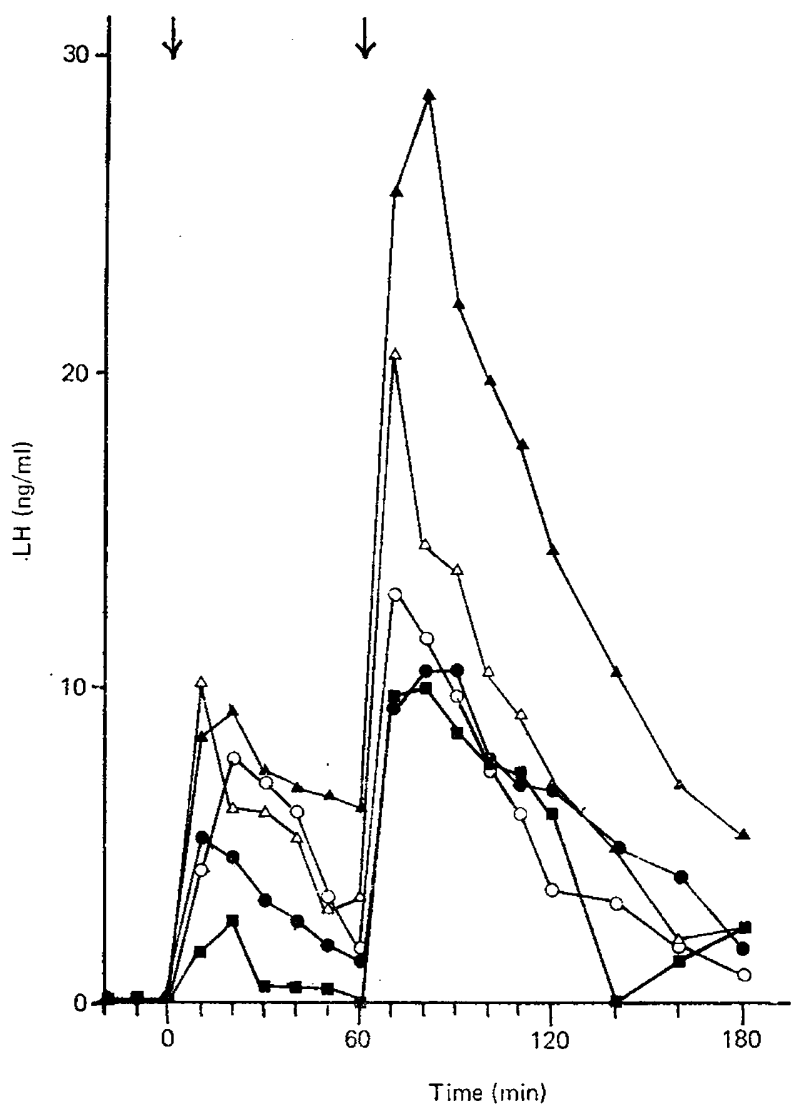

Text-fig. 1. Plasma LH levels in 5 Merino rams injected intravenously (arrows) with two $1 \mu \mathrm{g}$ doses of LH-RH 1 h apart.

The mean $\mathrm{LH}$ response to the second injection of LH-RH was significantly $(P<0.01)$ greater than the response to the first (Table 1; Text-fig. 1). The 5 experimental animals showed the same pattern of response, but the sensitivity of individual animals to the treatment differed (Text-fig. 1). When the first injection of LH-RH was replaced by saline in the control rams the response to LH-RH was no greater than to a single LH-RH injection (Table 1). Similarly, the saline injection following LH-RH treatment produced no significant increment in LH (Table 1). A single small dose of LH-RH administered intravenously to the ram therefore has the dual action of releasing some $\mathrm{LH}$ and sensitizing the pituitary so that greater amounts of LH are released by a second dose of LH-RH $1 \mathrm{~h}$ later.

In rams, biphasic patterns of LH response to a single large dose of LH-RH (Arimura, Debeljuk, Matsuo \& Schally, 1972) and to infusions (Bremner, Findlay, Cumming, Hudson \& de Kretser, 1976) have been reported previously. The priming effect demonstrated here by using two, much smaller, doses of LH-RH $1 \mathrm{~h}$ apart could present a clearer picture of the biphasic patterns of LH release. It is postulated that the first dose of LH-RH discharges some of the acutely releasable LH (equivalent to the first pool in the biphasic type of response; Bremner \& Poulsen, 1974) and sensitizes the pituitary gland to further treatment with LH-RH. In female animals a significantly greater release of LH in response to the second injection was found to be dependent on oestrogen and progesterone levels and protein and RNA synthesis (Aiyer $e$ t al., 1974; Pickering \& Fink, 1976a,b). The factors influencing the magnitude of the second, greater LH response to LH-RH in male animals remain obscure. The mechanism of the phenomenon in rams and its physiological significance are the subject of further study. 
The authors are indebted to Miss A. MacLeod for excellent technical assistance. This work was supported by Australian Wool Corporation.

\section{References}

AIYer, M.S., Chiappa, S.A. \& Fink, G. (1974) A priming effect of luteinising hormone releasing factor on the anterior pituitary gland in the female rat. J. Endocr. 62, 573-588.

Arimura, A., Debeluuk, L., Matsuo, H. \& Schally, A.V. (1972) Release of luteinizing hormone by synthetic LH-releasing hormone in the ewe and ram. Proc. Soc. exp. Biol. Med. 139, 851-854.

Bremner, W.J. \& Paulsen, C.A. (1974) Two pools of luteinising hormone in the human pituitary: evidence from constant administration of luteinising hormone releasing hormone. J. clin. Endocr. Metab. 39, 811-815.

BREMNER, W.J., FIndLAY, J.K., CUMming, I.A., HudSON, B. \& DE KRETSER, D.M. (1976) Pituitary-testicular responses in rams to prolonged infusions of LH-RH. Biol. Reprod. 15, 141-146.

Burger, H.G., Lee, W.W.K. \& RenNie, G.C. (1972) A generalised computer programme for the treatment of data from competitive protein binding assays including radioimmunoassays. J. Lab. clin. Med. 80, 302-312.

Crighton, D.B. \& Foster, J.P. (1977) Luteinising hormone release after two injections of synthetic luteinising hormone releasing hormone in the ewe. J. Endocr. 72, 59-67.

Hopkinson, C.R.N., PANT, H.C. \& Fitzpatrick, R.J.
(1974) Release of LH and FSH in the normal intact ram by synthetic LH-RH and the effect of pretreatment with testosterone propionate. J. Reprod. Fert. 39, 135-139.

Normand, M. \& Fortier, C. (1970) Numerical versus analytical integration of hormonal disappearance data. Can. J. Physiol. Pharmac. 48, 274-281.

Olivier, G.C. \& Faure, N. (1976) Hypersensitivity of the gonadotrophs to the repeated administration of small doses of LH-RH. Proc. 6th Int. Congr. Endocr., Hamburg, p. 131, Abstr.

Pickering, A.J.M.C. \& Fink, G. (1976a) Priming effect of luteinizing hormone releasing factor: in-vitro and in-vivo evidence consistent with its dependence upon protein and RNA synthesis. $J$. Endocr. 69, 373-379.

Pickering, A.J.M.C. \& Fink, G. (1976b) Priming effect of luteinizing hormone releasing factor: in-vitro studies with raised potassium ion concentration. J. Endocr. 69, 453-454.

Rommler, A. \& Hammerstein, J. (1974) Time dependent alterations in pituitary responsiveness caused by LH-RH stimulations in man. Acta. endocr., Copenh., Suppl. 184, 21, Abstr.

Wang, C.F., LAsley, B.L., Lein, A., and Yen, S.S.G. (1976) A functional change of the pituitary gonadotrophs during the menstrual cycle. J. clin. Endocr. Metab. 42, 718-728. 